\title{
Assessing inland excess water risk in Kanjiza (Serbia)
}

\author{
IMRE NAĐ ${ }^{1,2}$, VLADIMIR MARKOVIĆ ${ }^{1}$, MARKO PAVLOVIĆ $^{3}$, UGLJEŠA STANKOV $^{1}$, \\ GORDANA VUKSANOVIĆ ${ }^{4}$
}

1 University of Novi Sad, Faculty of Sciences, Department of Geography, Tourism and Hotel Management, Serbia; e-mail: vladimir.markovic@dgt.uns.ac.rs

2 Kaposvar University, Department of Regional and Environmental Studies, Hungary

3 IT Project Manager and Business Developer at Enlight IT Sourcing, Serbia

${ }^{4}$ Novi Sad Business School, Higher Education Institution for Applied Studies, Serbia

ABSTRACT Inland excess waters cause numerous considerable problems in economy, society and environment on a low lying parts of Serbia. The SEERISK methodology has been used for assessing the risk of inland excess water in Kanjiža municipality in Serbia. By applying the GIS tools, inland excess areas were extracted and categorization of different hazards level was done for following cover types: vegetable, orchard, crop, vineyard, grassland and forest. Analysing the satellite images for the selected period (March 2011, August 2012, April 2013 and June 2013), results show that four occurrences of inland excess water were recorded at $0.07 \%$ of territory, three occurrences at $0.53 \%$ of territory, two occurrences at $3.86 \%$, one occurrence at $9.26 \%$ and there were no occurrences at $86.28 \%$ of territory. As the final result, the risk map shows four inland excess water risk level zones ranked from "Low", "Medium", "High" to "Very high" which can be used by the local authorities in order to design strategies for reducing negative effects from inland excess water hazard.

KEY WORDS inland excess water - Kanjiža - risk assessment - groundwater - Seerisk

NAĐ, I., MARKOVIĆ, V., PAVlOVIĆ, M., STANKOV, U., VUKSANOVIĆ, G. (2018): Assessing inland excess water risk in Kanjiza (Serbia). Geografie, 123, 2, 141-158.

Received April 2017, accepted May 2018.

CC Česká geografická společnost, z. s., 2018 


\section{Introduction}

The term inland excess water refers to surplus surface water that can originate from different causes such as lack of runoff, insufficient absorption capability of soil or the upwelling of groundwater (Rakonczai et al. 2011). This phenomenon is temporary and it occurs in flat-lands due to both precipitation and groundwater emerging to the surface (Pásztor et al. 2015). When groundwater table increases the upwelling or vertical type of inland excess water occurs. The second most frequent type of inland excess waters is accumulative or horizontal type that forms under gravity in the lowest areas with limited infiltration and/or limited runoff, independent from the groundwater table or communicating by capillary system (Barta 2013). In general, excess water occurs regularly in the Carpathian Basin, usually at the end of winter and in spring and during summer every 2-4 years (Mezősi et al. 2014).

The term inland excess water received more scientific attention in Serbia as it is a reoccurring problem in the Carpathian Basin, but the problem exists in other European and Asian countries (Demin 2010, Barta 2013, Mezősi et al. 2014). Low lying, flat areas and local depressions with impermeable soils in the northern part of Serbia, which is the lowest part of the Carpathian basin, are also affected by the appearance of inland excess water. Despite the extensive hydro technical melioration measures that were undertaken during the last two centuries large agricultural areas, part of the settlements are endangered by this process (Pavić et al. 2014). In Vojvodina during 1956 approximately 230,000 ha was affected by inland excess waters. During the seventies, almost 130,000 ha (year 1970 127,000 ha; year 1975 - 128,000 ha) of agricultural areas were affected by the same hazard. In the year 1980 inland excess water floods extended on 146,700 ha. In the 1999 and 2000 more than 100,000 hectare was covered by the inland excess water that endangered more than 400,000 hectares of agricultural and settlement areas (Szatmári, Van Leeuwen 2013).

Inland excess waters and other disastrous hydrometeorological extremes cause numerous considerable problems in economy, society (Dolák, Brázdil, Valášek 2015) and also in environment in this part of Serbia (Obradović et al. 2014). As a predominantly agricultural region, inland excess waters cause severe damages to the crops and physically obstruct field activities. When appearing in the settlements, inland excess waters can cause damages to buildings, soil contamination because of sewer pits, slowing local traffic, etc. (Pavić et al. 2013) or even be displaced (Madić 2015). For the illustration, the agricultural damage in the municipality of Kikinda was approximately 22 million Euros just in 2010 (The Municipality of Kikinda, 2010).

Because of the complexity of this natural hazard and the fact that climate changes and their manifestation still represent one of the main topics of hydrology 
(Falátková et al. 2014), effect of inland excess water hazard is difficult to estimate. The study of Mezősi et al. (2014) showed that changing factors influencing inland excess water, such as groundwater and annual mean runoff decrease, increasing winter precipitation and overall decrease of available water resources have contradictory influences. Moreover, within that changing conditions in some drying environment inland excess water can have an important role in the recharging of subsurface water reservoirs.

Within different approaches to flood risk assessment (Tsakiris 2014), there are also different methods to assess inland excess water occurrences (Van Leeuwen et al. 2013). In order to assess the risk from inland water excess, we apply the SEERISK common methodology for risk assessment and mapping (PapathomaKöhle et al. 2013) of the municipality of Kanjiža, located in northern Serbia. The methodology was developed within the SEERISK project for risk assessment, risk awareness and development of suggestions on how to incorporate climatic aspects into existing territorial and sector-specific planning regimes to enable communities to make harmonized strategically elaborated actions. The municipality of Kanjiža is susceptible to this type of natural hazard due to its geographical circumstances related to the river Tisza.

Flood events on Tisza River in territory of Kanjiža were recorded in 1940, 1944, 1947, 1965, 1970, 2000, 2006, 2009 and 2010. The frequency of the occurrence of flood event has increased. By analysis of the previous flood events it can be concluded that there are two different triggers causing flooding: sudden snowmelt in upstream countries - mostly predominant in case of river flooding and heavy precipitation on watershed or extreme rainfall with more rainfall in shorter time interval - both for river and inland excess water events. Again simplifying the complex process of rainfall and runoff on entire Tisza watershed to rainfall and response in rise of the river water level the following conclusions can be drawn:

1. Water level for year 2010 was above the long-term average value.

2. Water level for year 2013 in February, March, April, May, June and mid-July was above the long-term average value.

3. For all other years $(2009,2011,2012)$ the water level was near the average longterm values.

4. Compared with the analysis for the yearly rainfall it can be stated that the main cause of higher water level than the long-term average was heavy rain.

\section{Site description}

The municipality of Kanjiža is located in northern part of the Republic of Serbia in Autonomous Province of Vojvodina and geographically extends from $45^{\circ} 55^{\prime}$ to $46^{\circ} 10^{\prime} \mathrm{N}$ latitude and from $19^{\circ} 48^{\prime}$ to $20^{\circ} 05^{\prime} \mathrm{E}$ longitude (Fig. 1). The municipality 
consists of 13 settlements. Kanjiža is the largest settlement and centre of municipality followed by Horgoš, Martonoš, Male Pijace, Mali Pesak, Orom, Doline, Novo Selo, Totovo Selo, Velebit, Adorjan, Zimonjić and Trešnjevac. According to the last census from year 2011, entire municipality has a population of 27,510 people out of which around 10,000 are living in Kanjiža settlement. The municipality has an administrative border on north with Hungary, on west with Subotica municipality and on south with Senta municipality. In the east, the transboundary river Tisza makes a natural border with the neighbouring municipality Novi Kneževac.

Overall the municipality covers an area of $399 \mathrm{~km}^{2}$. Average elevation of municipality is $87 \mathrm{~m}$ a.s.l. In geomorphologic aspect the entire territory consists of four distinguished areas: Tisza alluvium, loess sands, Subotica sands and Backa loess plateau. The last one Bačka loess plateau covers approximately $45 \%$ of entire territory of municipality. Out of 399,000 ha, approximately $75 \%$ or cca 300,000 ha is agricultural land. Only 150 ha of agricultural land is under some type of irrigation systems (Marković et al. 2016). Pedology of the territory is mosaic. It varies from chernozem soil type, salty soil and sandy soils to wetlands near water bodies.

According to Pavić et al. (2013), Tisza River Valley as one of the predominant landscapes in Kanjiža relief is the most vulnerable to inland excess water. However, conditions for formation of inland excess water exist also in local depression on higher geomorphologic units, such as loess terrace, loess plateau and sands, which are all present in Kanjiža municipality. Tisza is the largest tributary by cover area and third by discharge to the Danube River. It drains water from four countries (Ukraine, Slovakia, Hungary and Serbia) and has total length of $966 \mathrm{~km}$ out of which $164 \mathrm{~km}$ is on territory of Serbia. Due to alluvial landscape of Vojvodina Province average longitudinal profile is around $5 \mathrm{~m}$ or $0.028 \%$. This small, water mirror fall is predominant factor influencing the decrease of average water velocity causing the occurrence of river flood. Additional, contribution factor is modification of natural flow and straightening of the river bed carried in mid of $18^{\text {th }}$ century. With these measures taken the total flow of Tisza was shorted from $1,419 \mathrm{~km}$ to nowadays $966 \mathrm{~km}$.

National level alerts and available data often do not reach the relevant local authorities responsible for the intervention, and even more typically, the ones suffering from the consequences. The perception of citizens and the local authorities regarding the impacts of climate change varies by country and region, but it is generally inadequate (National Directorate General for Disaster Management 2013). The Spatial plan of the Republic of Serbia (2010), The Spatial plan of municipality of Kanjiža (2012) and the Operational plan of flood control, flooding from ground water and ice, which is aligned with other official (structures) plans of the Republic of Serbia (RSOG 2011), address the topic of risk management and assessment for inland excess water, but don't process it in particular. However, they emphasize the priority of the development of natural disaster protection system. 


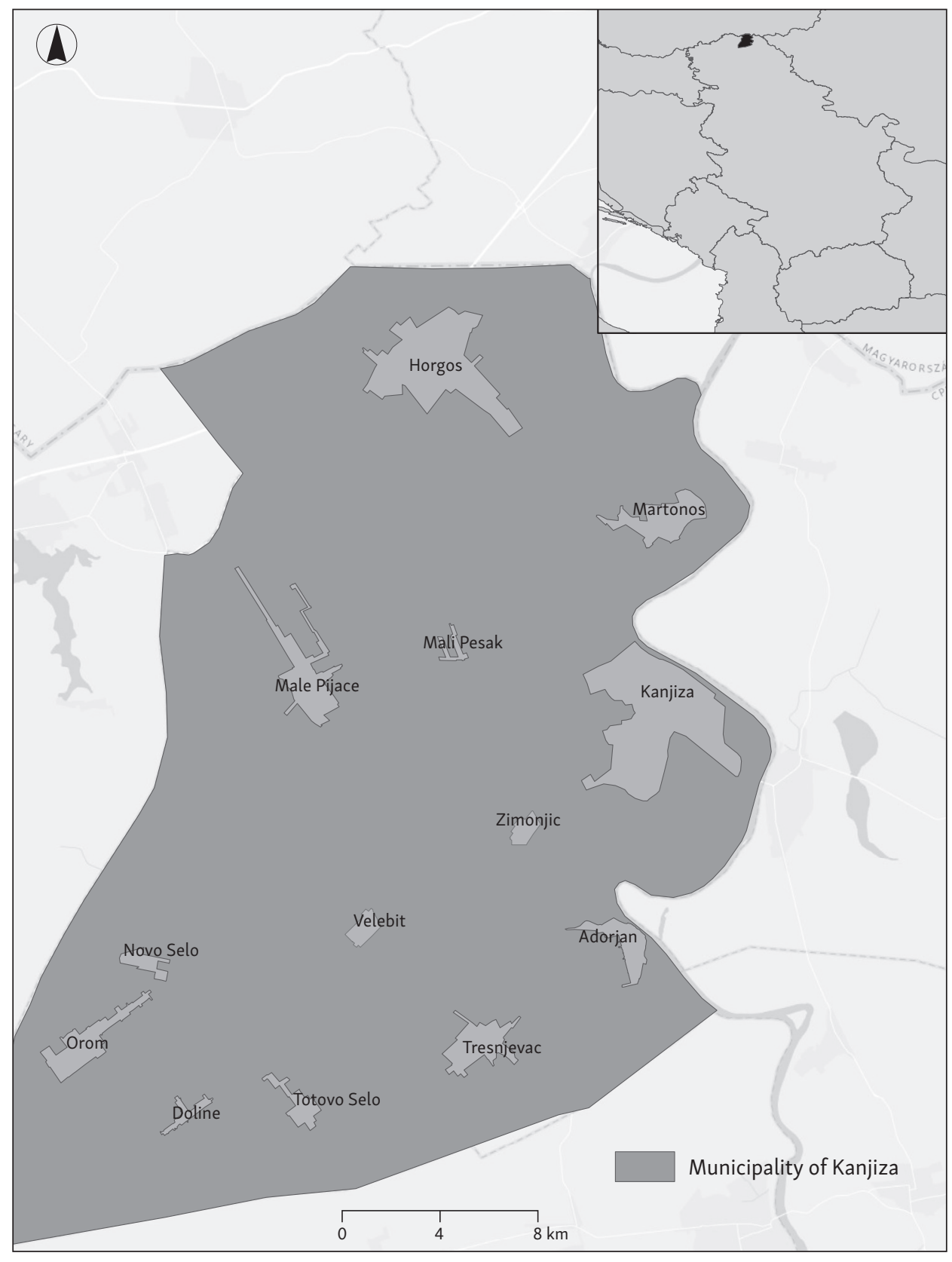

Fig. 1 - The study area Kanjiža in the Vojvodina region (Serbia) 


\section{Data and methodology}

The methodology has been designed in accordance with the European Commission's guidelines for risk assessment and mapping (EC 2010). The methodology developed within the SEERISK project it has been adapted for five climate change related hazard types: flood, drought, heat wave, wildfire and extreme winds. The principal aim of the methodology is to provide a tool for local experts that can assist them in the implementation of risk assessment and in the estimation of potential changes of risks associated with specific scenarios, including climate change related scenarios. The methodology provides a step-wise approach, regarding the risk assessment procedure, a methodology on the development of risk matrices and scenarios and finally a theoretical approach to risk mapping applicable to all hazard types, which have been in the focus of SEERISK project. Risk assessment incorporates establishing the context and risk identification, risk analysis and risk evaluation. Records of past events have to be investigated first, in order to obtain information on the probability of occurrence and the intensity of each event. Information regarding the impact of specific events has to be collected and analysed. Impact analysis involves collection of information regarding a specific element at risk and the risk metric. The identification of the elements at risk in the study area and their characteristics that affect their vulnerability has to be included. The impact rating is based on real past events and their consequences or expert judgment (National directorate general for disaster management 2014). It incorporates the development of a hazard and an impact map that will lead to a quantitative or a qualitative risk map according to the available data (PapathomaKöhle et al. 2013).

The risk assessment process incorporates following steps:

1. The development of a hazard map

2. The development of an impact map

3. The development of a risk matrix by implementing the following actions based on information on past events:

- Indicating the likelihood or probability of occurrence of inland excess water events

- Indicating the impact inland excess water on cover type

- Setting the inland excess water risk levels (very low, low, medium, high, very high)

4. Overlay of the above maps and development of a risk map showing the different risk levels as they have been rated in the risk matrix.

In the risk assessment, inland excess water frequency is defined as a hazard. The study area is divided into cells $100 \mathrm{~m} \times 100 \mathrm{~m}$ where number of recorded occurrences of inland excess water represents the hazard level. By applying the GIS tools 


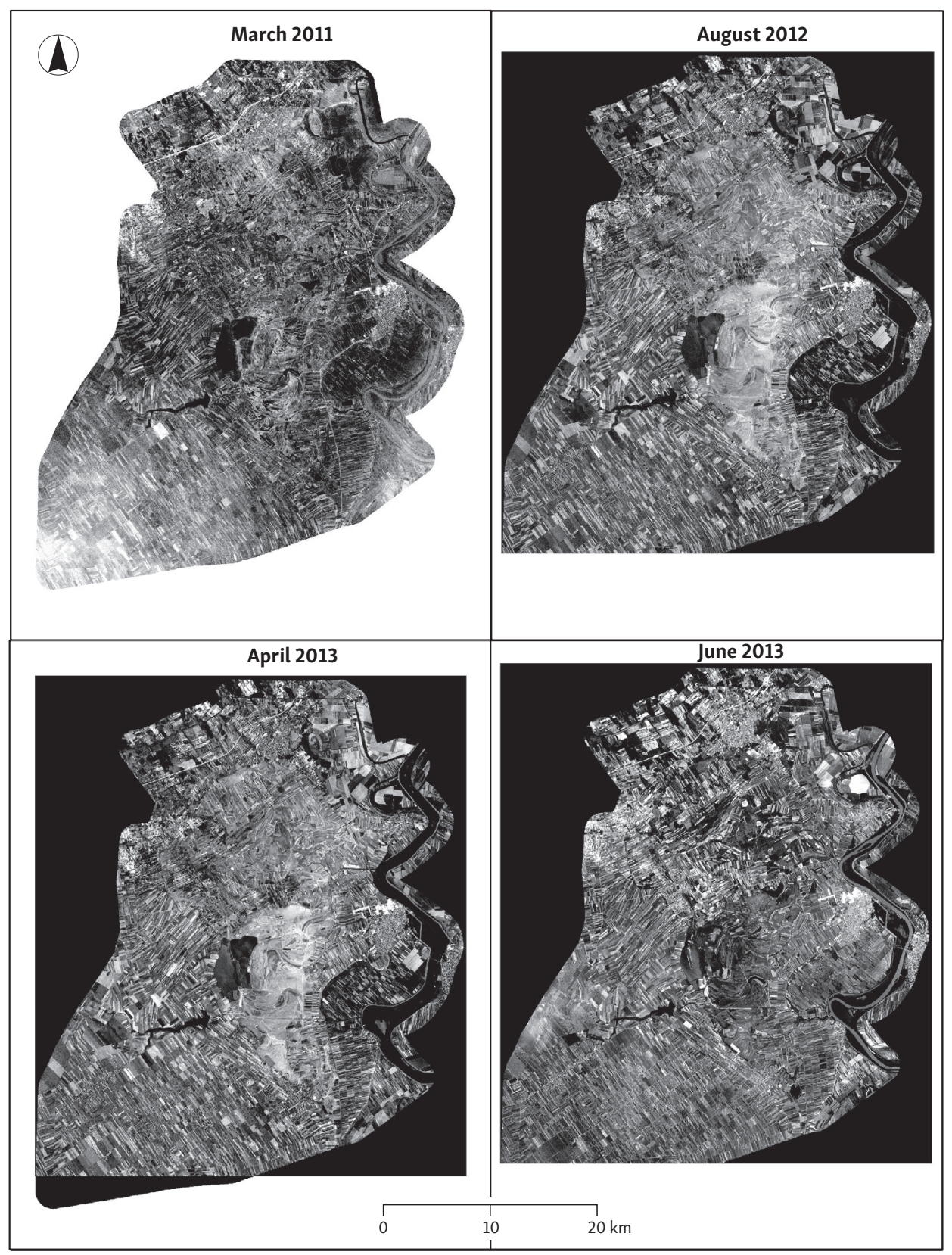

Fig. 2 - Satellite images for the selected period 
it was possible to extract areas only covered with inland excess water. The flooding frequency values were reclassified from very low (0) to very high (4) hazard levels according to the number of repeating of inland excess water occurrence in each cell. The hazard map is derived from the analysis of the satellite images (Fig. 2) for the selected period (March 2011, August 2012, April 2013 and June 2013).

In this study, impact refers to the land cover type represented by vulnerability level, i.e. to the potential damage loss due to the inland excess water. The vulnerability of land cover was reclassified from Insignificant (0) to Very high (5) impact level according to the potential damage loss due to the inland excess water. In the projection condition, the inland excess water covers mostly plantations and agriculture land. Agricultural land is situated in low lying regions where the soil is most fertile and in terms of crops growing, where it can take advantage of normal flooding, bringing nutrients that increase soil fertility. This, however, leaves prime agricultural land susceptible to inland excess water flooding, leaving crops vulnerable to destruction. All infrastructures from civil protection point of view are excluded due to focusing only to the agricultural purposes, because these types of floods are not life dangerous and usually they don't affect settlement built on higher grounds.

Both hazard and impact maps were join to the same feature class using the GIS tools. In this order each impact category was assigned to related hazard category. The number of classes depends on the number of either impact or hazard categories. In order to generate risk categories for each mapping unit, these hazards and impact numbers need to be combined in a mathematical way. One option is to use simple multiplication; another one is to derive the results with place-value addition (the first digit stands for the hazard category and the second digit corresponds to the impact category).

The risk map was generated by place-value addition from the hazard and impact maps using the Raster Calculator tool, based on the equation (risk value) = $10 \times($ hazard level $)+($ impact level). The calculated risk values were reclassified to risk levels according to the colouring of the risk matrix and resulted in the risk maps. The output is a qualitative risk map.

The geographical location and relief are predominant factors in definition of climate of the Kanjiža territory. All necessary data series are taken from Republic Hydrometeorological Service of Serbia (RHMSS), meteorological yearbooks for the meteorological stations in or in near Kanjiža municipality (Palić, Zrenjanin, Kikinda) and local meteorological stations (Adorjan, Martonoš, Horgoš and Male Pijace). In order to get the full understanding of the hydrological processes data about the rainfall amounts for the selected periods were collected and analysed. Average rainfall for March 2011 was above the long-term average rainfall for period 1953-2010 for March. The interval was between 15\% and 49\% above the longterm average values. The period can be characterised as moderate to extremely 
wet. Average rainfall for August 2012 was extremely below the long term average rainfall for period 1953-2010 for August. The interval was between $82 \%$ and $88 \%$ below the long-term average values. The time period can be characterised as extremely dry. Average rainfall for April 2013 was slightly below the long term average rainfall for period 1953-2010 for April. The interval was between 0 to $9 \%$ below the long-term average values. The period can be characterised as average. Average rainfall for June 2013 was below the long-term average rainfall for period 1953-2010 for June. The interval was between $12 \%$ and $62 \%$ below the long-term average values. The time period can be characterised as moderate to extremely dry.

\section{Results}

\subsection{Analysis of the groundwater levels and inland excess water for selected time period}

For selected time period 2009-2013, data for the groundwater level on five RHMSS piezometer stations were analysed. The data set was extracted from the Hydrological yearbook 2009, 2010, 2011, 2012 and 2013 for the piezometer stations in profile: Kanjiža TKA-1D (24.79 m depth, 0.6 km from Tisza), Kanjiža TKA-2D (26.08 m depth, $3.26 \mathrm{~km}$ from Tisza), Kanjiža TKA-3 (9.29 m depth, $0.58 \mathrm{~km}$ from Tisza), Kanjiža TKA-4 (9.13 m depth, 0.94 km from Tisza) and Kanjiža TKA-5 (9.08 m depth, $1.54 \mathrm{~km}$ from Tisza; RHMSS 2013). The long term average of the groundwater level for these five stations were calculated as well from the RHMMS yearbooks from 1995 to 2008.

By simplifying the outcomes from the above figures and using the plain rainfall - infiltration process as direct impact of the rainfall to the rise of the groundwater level. For 2009 and 2012 groundwater levels were bellow long term average values. On the other hand, for year 2011, 2011 up until august and 2013 from April the groundwater levels were above the long term average values from 1995-2008.

\subsection{Hazard map}

Accordingly in order to provide the GIS interpretation of one specific risk type inland excess water on Kanjiža municipality, hazard and values were defined, categorised and calculated separately. For the proper agricultural planning and management of inland excess water it is crucial to have detail information about flood extension. Accordingly, in this study the propagation of inland excess water was analysed using the distribution of four days floods in both space and time. This map indicates the number of cells where the higher the number of recorded inland excess water occurrences in a cell, the greater the flood risk. The multi polygons 
Table 1 - Hazard categories and levels for inland excess water

\begin{tabular}{lccl}
\hline Frequency of flooding & Affected territory (\%) & Hazard category & Hazard level \\
\hline four times & 0.07 & 4 & Very High \\
three times & 0.53 & 3 & High \\
two times & 3.86 & 2 & Medium \\
one time & 9.26 & 1 & Low \\
no floodings & 86.28 & 0 & Very Low \\
\hline
\end{tabular}

for the selected time period were merged together for which hazard categories were assigned as well as corresponding hazard levels (Table 1).

Hazard inland excess water map for the Kanjiža municipality showing different hazard levels and the location of these levels are represented in the Figure 3.

Hydrologic models play a major role in assessing and forecasting flood risk. This kind of models can help stakeholders to develop contingency plans in advance to help facilitate a more effective response. According to this hazard frequency, from total of 81.098 cells, all four occurrences were recorded in 60 cells $(0.07 \%$ of territory). Closer look on Figure 4. depicts that the worst condition of inland excess water (which are under colour black) are scattered across the area and could not cause heavy damages in greater extent. On the other hand, three occurrences of inland excess water were recorded in 427 cells ( $0.53 \%$ of territory), two occurrences in 3.133 cells ( $3.86 \%$ of territory), one occurrence in 7.513 cells $(9.26 \%$ of territory) and there were no occurrences in 69.965 cells ( $86.28 \%$ of territory). What's more, areas under other hazard levels are closer to each other, so it is possible to extract the most vulnerable areas as: eastern, north-eastern and northwestern parts of the municipality. Figure 4 can serve as a basis for detailed analysis providing quantitative statements about the extent, intensity and consequences of relevant hazard.

\subsection{Impact map}

Knowledge of spatial distribution of land cover is an asset to decision makers and stakeholders to efficiently provide support to affected areas. Impact map was created by differentiation of the land cover types in the Kanjiža municipality. First division was made between the urban areas (settlements), other areas (e.g. roads) and agricultural areas. Among the agricultural areas further distension was made among:

1. Area with predominantly vegetable productions.

2. Area with predominantly orchard.

3. Area with predominantly different crop types. 


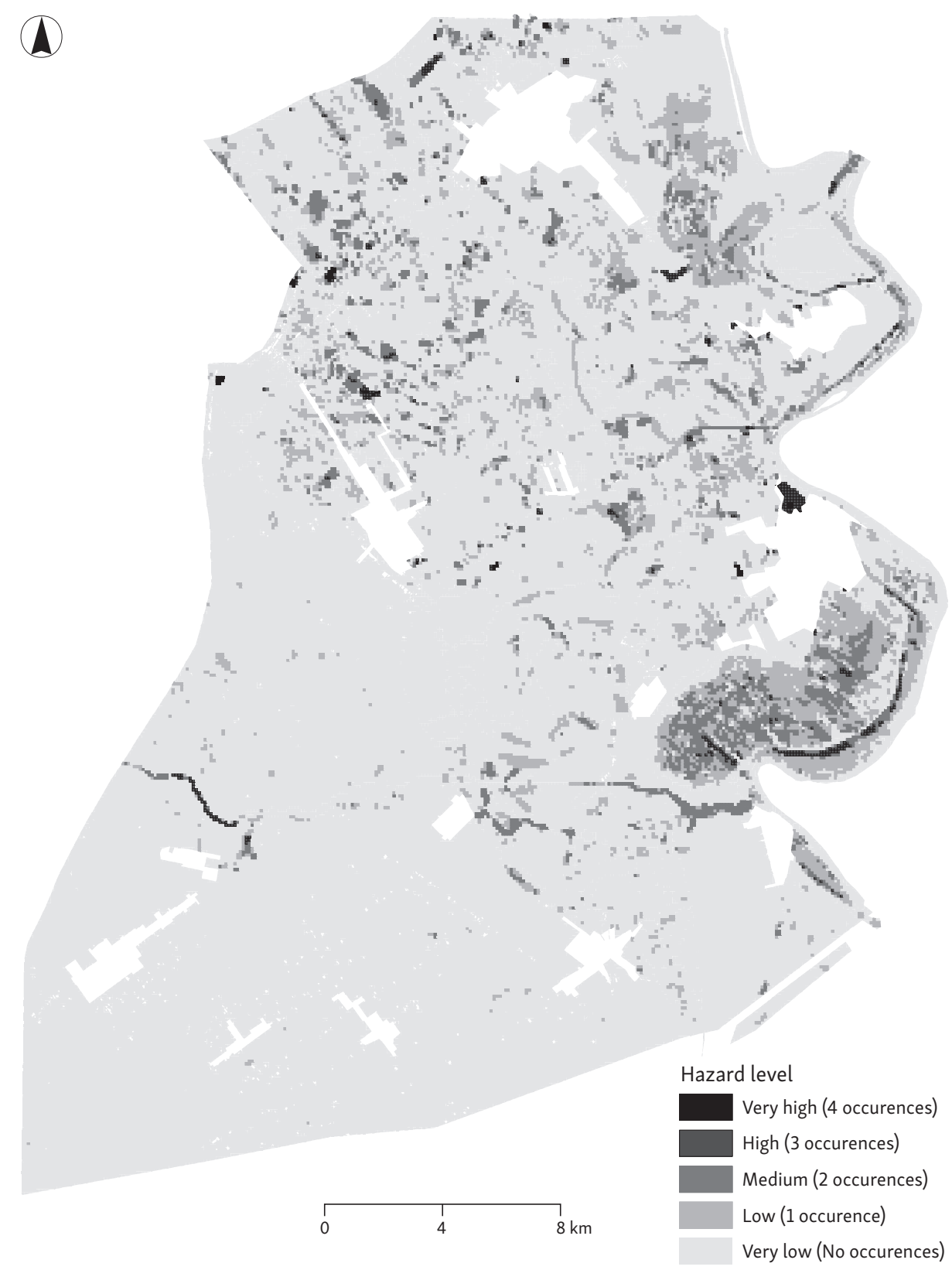

Fig. 3 - Hazard map of inland excess water in Kanjiža municipality 
4. Area with predominantly vineyard.

5. Area with predominantly grassland.

6. Area with predominantly forest.

7. Area with predominantly water and wetland.

Taking in account land cover (Papathoma-Köhle et al. 2013) and vulnerability level to the potential damage loss due to the inland excess water impact categorisation and impact levels were made (Table 2).

Impact map for the Kanjiža municipality showing different impact levels and the location of these levels are represented in the Figure 4.

Satellite images combined with localizes expertise from agricultural producers enabled diversification of cover types in selected territory. Predominant coverage of seasonal crops can be further decomposed to certain crop types, however smaller crop granulation would not have different impact than grouped giving in consideration two parameters. One pointing to the fact that main economical income in municipality of Kanjiža coming from agriculture is from crop types (corn, wheat, sugar beet, etc.) and second related to the coverage of crops in municipal arable land we denoted highest impact level to this cover type.

In order to evaluate the impact of flooding on agriculture land, the submerged area was classified into six classes. The impact map clearly shows locations of the vulnerable locations. As Figure 4 shows that crops as very high impact level covers most of the municipality area (76.75\%). From this map it can be seen that crops encompass all parts except central and north-western parts. The high impact level - vegetable fields cover $0.43 \%$ of the territory. Orchards and vineyards as medium impact level covers $3.63 \%$. Grasslands as low impact level covers $11.43 \%$, while forest as very low impact level cover $2.43 \%$ of the territory. Water bodies and wetlands occupy $5.33 \%$ and are not considered as element at risk.

Table 2 - Impact categories and levels for agricultural areas

\begin{tabular}{lccl}
\hline Cover type & Affected territory (\%) & Impact category & Impact level \\
\hline Crop & 76.75 & 5 & Very High \\
Vegetable & 0.43 & 4 & High \\
Orchard and vineyard & 3.63 & 3 & Medium \\
Grassland & 11.43 & 2 & Low \\
Forest & 2.43 & 1 & Very Low \\
Water, Wetlands & 5.33 & 0 & Not considered to be at risk \\
\hline
\end{tabular}




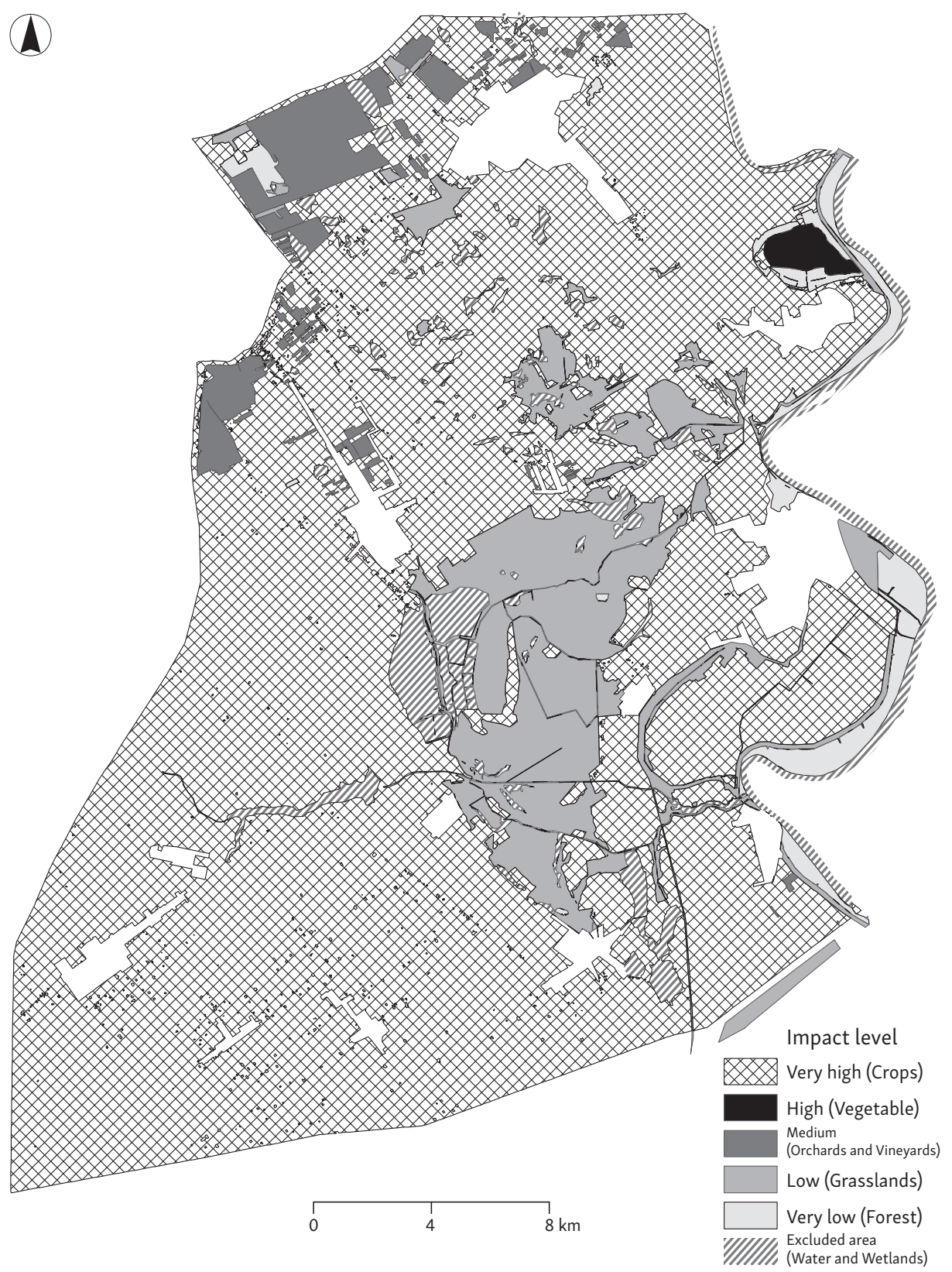

Fig. 4 - Impact map for agricultural area in Kanjiža municipality 
Table 3 - Risk matrix for inland excess water for Kanjiža municipality

\begin{tabular}{lllllll}
\hline Impact level & Very high & 05 & 15 & 25 & 35 & 45 \\
& High & 04 & 14 & 24 & 34 & 44 \\
& Medium & 03 & 13 & 23 & 33 & 43 \\
& Low & 02 & 12 & 22 & 32 & 42 \\
& Very low & 01 & 11 & 21 & 31 & 41 \\
\hline Hazard level & & Very low & Low & Medium & High & Very high \\
\hline
\end{tabular}

\subsection{Risk matrix and risk map}

The risk values can be than classified based on the colouring of the risk matrix based upon expert judgement. Each two-digit risk value is ranked from "very low" to "very high", although these colours represent risk categories in numbers again (Table 3).

The risk map was generated from the risk matrix according to the risk level distribution (Fig. 5). The calculated risk values were reclassified to risk levels according to the above-mentioned scheme.

As Figure 5 shows the occurrence of very high risk level is presented with $2.79 \%$ of total vulnerable area. This risk level category is prone to risk due to direct and indirect exposure to excess water not only during the hazardous event but after one as well. Although this study is focused on agriculture, excess water can contaminate water supply wells, lead to structural damages to housing and infrastructure due to soil erosion effect, etc.

High risk level occupy $6.85 \%$, medium risk level $0.43 \%$, while the most of the vulnerable areas are marked as low risk level which encompasses $84.60 \%$. Excluded area such as water bodies and wetlands encompass $5.33 \%$ of total territory. In past, this area was naturally covered with water in permanent or frequency occurrence, thus the lowest risk level category.

\section{Discussion}

The objective of this study was to investigate impact and hazard of inland excess water in Kanjiža municipality and to assess and map the associated risk. According to results high risk areas correspond with areas characterized by high hazard and high impact. For areas affected by inland excess water like Kanjiža municipality, risk assessment is very essential for design of mitigation measures. When hazard occurs the identification of potential points can help to moderate negative economic impact. The assessment of risk is one of the main aspects of inland excess 


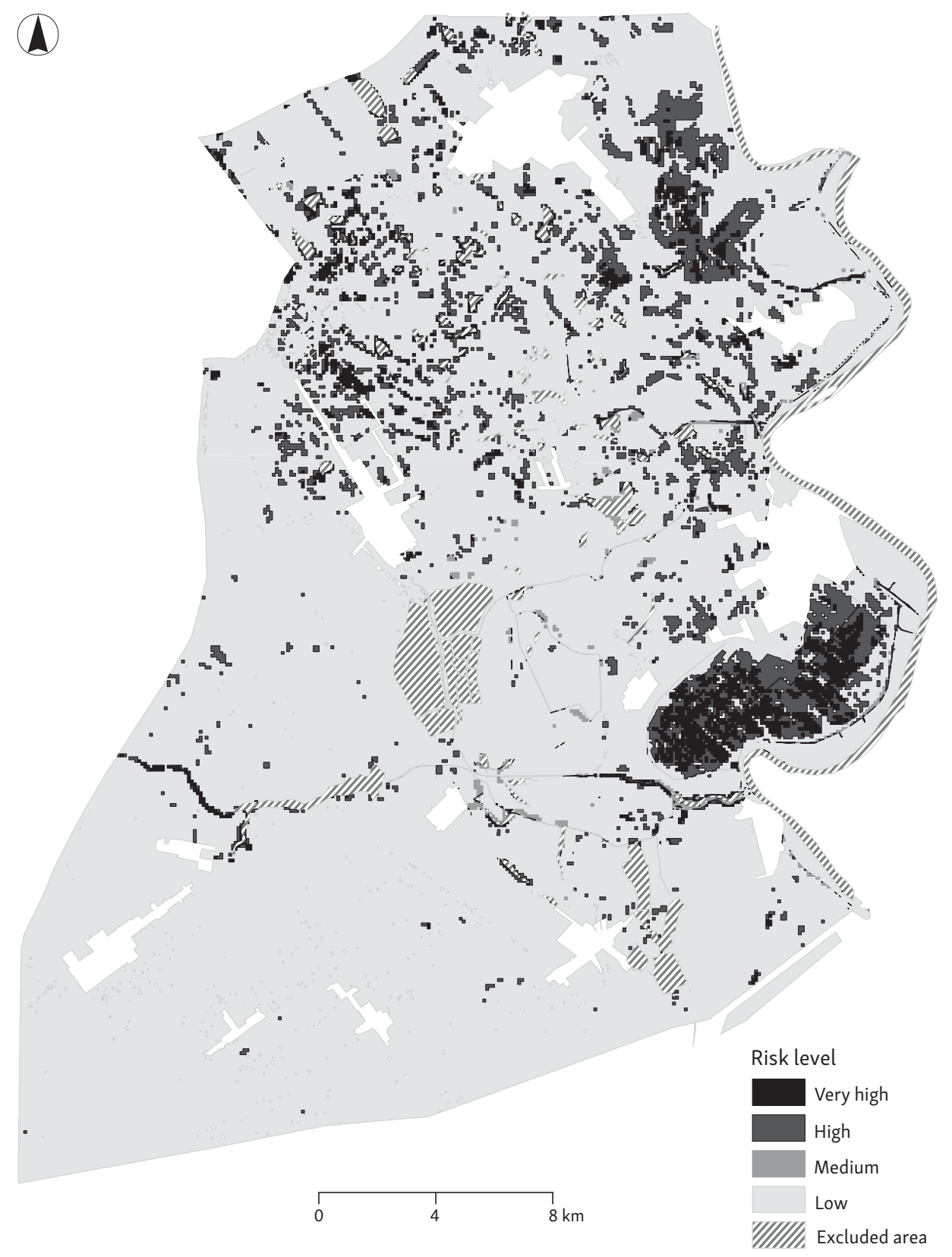

Fig. 5 - Risk map for inland excess water of Kanjiža municipality 
water mitigation and given maps as well as study in general can strengthen the operational responses of the authorities.

Presented methodology could be applied to other municipalities that also belong to ground water flooded areas (Tisza and Danube areas). This way unique set of criteria's can be applied to wider area enabling regional prioritization of activities needed to be taken in order to mitigate the inland excess water in predominantely agricultural region.

The major advantages of the methodology presented here were that it integrated existing data using a simple defensible methodology to indicate areas at different level of risks. The approach could lead a number of initiatives for making full-use of the functional capabilities of GIS. The use of GIS enables the updating of the database helping in this way the decision makers to consider future changes not only concerning the water regime but also the spatial pattern of the elements at risk. Furthermore, field researches could identify places they seek to investigate with greater spatial precision. Finally, presentation of risks on visually appealing and easily understandable manner enable by GIS alters the risk perception of decision makers and the public awareness supporting in this way effective risk management.

However many limitations and shortcomings are associated with the application of the specific methodology. Firstly, concerning the impact assessment, due to almost annually changes in land cover (planting different crops) the yearly update impact inputs every year is considered essential although it would increase the mapping costs. Moreover, the the determination of hazard scenarios is very limited. It could not be considered (because of availabilty of data) that the most relevant scenarios are included in the analysis. Thirdly, the constraints for GIS applications in developing counties must be overcome to reap maximum benefits of these promising technologies (Jha, Chowdary 2007). There are very limited efforts to develop a GIS systems. Due to lack of data many assumptions have to be made increasing in this way the level of uncertainty in the study. As mention above, the main limitation of the methodology is the lack of reliable good quality data. Even though the results may be uncertain, such risk assessment may be very useful.

This preliminary study could be a starting point for future investigation of inland excess water in Kanjiža municipality. The study could be beneficial to a number of stakeholders - particularly agricultural organizations, planning authorities, risk insurers and others to improve their understanding on inland excess water impacts. Finally, it can be concluded that presented SEERISK methodology has great potential to revolutionize inland excess water risk assessment and management in the future by providing unique insight and new data to supplement the conventional field research. 


\section{Conclusion}

The present paper succinctly highlights GIS technologies and presents a stateof-the-art methodology on the application of this emerging technique in inland excess water risk assessment and management. The use of GIS has proven usefulness, potentiality and capability to assess and monitor the flood event as well as inland excess water event. The research presented here illustrates the application of the SEERISK Common risk assessment methodology on inland excess water hazards in Municipality of Kanjiža (Serbia). The risk map developed can be used to give a quick estimate whether there is a high, medium, low or very low risk in the affected area. The investigation of map results may lead to an easier update of local action and development plans and legislation by taking into account the inland excess water hazard. Thus, this study confirms that this kind of methodology is of value for inland excess water investigations and analysis.

Such advancements will certainly enable us to develop and manage precious inland excess water risk assessment in a real sustainable and environment-friendly way across the Serbia, and other areas which face similar natural hazard.

\section{References}

BARTA, K. (2013): Inland Excess Water Projection based on Meteorological and Pedological Monitoring Data on a Study Area Located in the Southern Part of The Great Hungarian Plain. Journal of Environmental Geography, 6, 3-4, 31-37.

DEMIN, A.P. (2010): Water management complex of Russia: Concept, state of the art, and problems. Water resources, 37, 5, 711-726, DOI: 10.1134/S009780781.

DOLÁK, L., BRÁZDIL, R., VALÁŠEK, H. (2015): Impacts of hydrometeorological extremes in the Bohemian-Moravian highlands in $1706-1889$ as derived from taxation records. Geografie, $120,4,465-488$.

EC (2010): Staff Working Paper on Risk Assessment and Mapping Guidelines for Disaster Management. European Commission, Brussels.

FALÁTKOVÁ, K., ŠOBR, M., KOCUM, J., JANSKÝ, B. (2014): Hydrological regime of Adygine lake, Tien Shan, Kyrgyzstan. Geografie, 119, 4, 320-341.

JHA, M.K., CHOWDHURY, V.M. (2007): Challenges of using remote sensing and GIS in developing nations. Hydrogeology Journal, 15, 197-200.

MADIĆ, S. (2015): Molin - The village that disappeared from the Central Banat. Researches review of the Department of geography, tourism and hotel management, 44, 2, 146-159.

MARKOVIĆ, V., NAGY, I., SZIK, A., PERGE, K., LASZLO, P., PAPATHOMA-KOHLE, M., PROMPER, C., GLADE, T. (2016): Assessing drought and drought related wildfire risk in Kanjiza, Serbia-the SEERISK methodology. Natural Hazards, 80, 2, 709-726, DOI: 10.1007/ s11069-015-1991-4.

MEZŐSI, G., BATA, T., MEYER, B. C., BLANKA, V., LADÁNYI, Z. (2014): Climate change impacts on environmental hazards on the Great Hungarian Plain, Carpathian Basin. International Journal of Disaster Risk Science, 5, 2, 136-146, DOI: 10.1007/s13753-014-0016-3. 
THE MUNICIPALITY OF KIKINDA (2010): Saopštenja Gradskog veća. http://www.kikinda. org.rs/index.php?language=lat\&page=samouprava\&option=saopstenjaopstinskogveca\&str ana $=3 \&$ godina $=2010$ (1.11.2015, in Serbian).

National Directorate General for Disaster Management. (2013): Social awareness questionnaire - SEERISK, https://seerisk.rsoe.hu/share/page/site/seerisk-project/document (4.11.2015).

National Directorate General for Disaster Management. (2014): Guideline on climate change adaption and risk assessment in the Danube Macro-region, http://www.rsoe.hu/projectfiles/ seeriskOther/download/climate_change_adaptation.pdf (16.2.2015).

OBRADOVIĆ, Đ., DOGAN, V., ŽIVANOV, M., KAROLY, B. (2014): Hardware realisation of data logger system for inland excess water. In Dokić, B. (ed.): Symposium proceedings of X Inernational Symposium on Industrial Electronics. Faculty of Electrical Engineering, Banja Luka, 155-159.

PAPATHOMA-KÖHLE, M., PROMPER, C., GLADE, T., SZEKELY M. (2013): SEERISK: Common risk assessment methodology for the Danube macro-region, https://seerisk.rsoe.hu/share/ page/site/seeriskproject/documentdetails?nodeRef=workspace://SpacesStore/656bod96bc9e-4a67-8f99-3805087533f9 (4.11.2015).

PÁSZTOR, L., KÖRÖSPARTI, J., BOZÁN, C., LABORCZI, A., TAKÁCS, K. (2015): Spatial risk assessment of hydrological extremities: Inland excess water hazard, Szabolcs-Szatmár-Bereg County, Hungary. Journal of Maps, 11, 4, 636-644, DOI: 10.1080/17445647.2014.954647.

PAVIĆ, D., MÉSZÁROS, M., DOLINAJ, D., SAVIĆ, S., OBRADOVIĆ, D., BRKIĆ, M., ŽIVANOV, M. (2013): Inland excess water in Vojvodina, (Serbia) - innovative methods in cross border research for an old, common problem. In: Lóki, J. (ed): Az elmélet és a gyakorlat találkozása a térinformatikában IV. Debreceni Egyetemi Kiadó, Debrecen, 89-96.

PAVIĆ, D., MESAROŠ, M., SAVIĆ, S. DOLINAJ D., MILOŠEVIĆ, D. (2014): Inland excess water monitoring in Vojvodina (Serbia). In: Mimica Dukić, N., Filipović, D. (eds.): The Third Romanian-Bulgarian-Hungarian-Serbian conference, Geographical Research and Cross-Border Cooperation within the Lower Basin of the Danube. Faculty of Science, Novi Sad, 29-30.

RAKONCZAI, J., FARSANG, A., MEZŐSI, G., GÁL, N. (2011): A belvízképződés elméleti háttere. Theoretical background of the formation of inland excess water. Földrajzi közlemények, 135, 4, 339-349.

RHMSS (2013): Meteorological yearbook. Republic Hydro-meteorological Service of Serbia, Belgrade.

RSOG (2011): National strategy for the protection and rescue in emergency situations, RS Official Gazette, No.86/11, http://www.mup.gov.rs/cms_lat/sadrzaj.nsf/Nacionalna_strategija_zastite_i_spasavanja_u_vanrednim_situacijama_lat.pdf (12.11.2015).

SZATMÁRI, J., VAN LEEUWEN, B. (2013): Inland Excess Water. University of Szeged, Department of Physical Geography and Geoinformatics, Szeged.

Spatial Plan of Republic of Serbia (2010): National Assembly of Republic of Serbia, http:// 195.222.96.93//media/zakoni/Spatial\%20Plan\%20of\%20the\%20Republic\%20of\%20Serbia_2010-2020_abridged\%20(1).pdf (4.12.2015).

Spatial Plan of Municipality of Kanjiza (2012): National Assembly of Republic of Serbia, http:// www.kanjiza.rs/dokumentumok/2012/mk_teruleti_terv_tervezet/ppo_kanjiza_nacrt/ ppo_kanjiza_nacrt.pdf (2.12.2015).

TSAKIRIS, G. (2014): Flood risk assessment: concepts, modelling, applications. Natural Hazards and Earth System Sciences 14, 1361-1369, DOI: 10.5194/nhess-14-1361-2014.

VAN LEEUWEN, B., HENITS, L., MÉSZÁROS, M., TOBAK, Z., SZATMÁRI, J., PAVIĆ, D., SAVIĆ, S., DOLINAJ, D. (2013): Classification methods for inland excess water modelling, Journal of Environmental Geography 6, 1-2, 1-11, DOI: 10.2478/v10326-012-0001-5. 